\title{
Comparison Between Normobaric Hypoxia Altitude Simulation Test and Altitude Hypoxia Predictive Equations in Cystic Fibrosis Patients
}

\section{Christine Costa ${ }^{1}$, André Barros ${ }^{2}$, João Valença Rodrigues ${ }^{1}$, Richard Staats ${ }^{1}$, Mariana Alves $^{1}$, Pilar Cardim¹, Carlos Lopes ${ }^{1}$, Cristina Barbara ${ }^{1}$, Luís F. Moita ${ }^{2,3}$, and Susana Moreira ${ }^{1,2}$}

${ }^{1}$ Centro Hospitalar Lisboa Norte, Serviço de Pneumologia, Departamento do Tórax, 1649-035 Lisboa, Portugal.

${ }^{2}$ Instituto Gulbenkian de Ciência, Rua da Quinta Grande 6, 2780-156 Oeiras, Portugal. ${ }^{3}$ Instituto de Histologia e Biologia do Desenvolvimento, Faculdade de Medicina da Universidade de Lisboa, 1649-028 Lisboa, Portugal

Corresponding author: Christine Costa (christinesilvacosta@gmail.com), Luís

Moita (1moita@igc.gulbenkian.pt) or Susana Moreira (susanalmoreira@gmail.com)

\section{Abstract}

Background: The Hypoxia Altitude Simulation Test (HAST) is the Gold Standard to evaluate hypoxia in response to altitude and to decide on in-flight requirements for oxygen supplementation. Several equations are available to predict $\mathrm{PaO}_{2}$ in altitude $\left(\mathrm{PaO}_{2 \text { alt }}\right)$, but it remains unclear whether their predictive value is equivalent. We aimed to compare the results obtained by the available methods in a population of cystic fibrosis (CF) adults. Methods: Eighty-eight adults (58 healthy controls and $30 \mathrm{CF}$ patients) performed a spirometry followed by an HAST. HAST results were compared with the predicted $\mathrm{PaO}_{2}$ alt made by five equations: $1^{\text {st: }} \mathrm{PaO}_{2 \text { alt }}=0,410 \times \mathrm{PaO}_{2 \text { ground }}+$ 1,$7652 ; 2^{\text {nd }}: \mathrm{PaO}_{2 \text { alt }}=0,519 \times \mathrm{PaO}_{2 \text { ground }}+11,855 \times \mathrm{FEV}_{1}(\mathrm{~L})-1,760 ; 3^{\text {rd }}: \mathrm{PaO}_{2 \text { alt }}=0,453$ $\times \mathrm{PaO}_{2 \text { ground }}+0,386 \times \mathrm{FEV}_{1}(\%)+2,44 ; 4^{\text {th }}: \mathrm{PaO}_{2 \text { alt }}=0,88+0,68 \times \mathrm{PaO}_{2 \text { ground }} ; 5^{\text {th }}$ : $\mathrm{PaO}_{2 \text { alt }}=\mathrm{PaO}_{\text {2ground }}-26,6$. Results: None of the controls required in-flight oxygen neither by HAST or by the five predictive equations. Eleven CF-patients had $\mathrm{PaO}_{2}$ alt $<$ $50 \mathrm{mmHg}$, accessed by HAST. The positive predictive value was $50 \%\left(1^{\mathrm{st}}\right), 87.5 \%\left(2^{\text {nd }}\right.$ and $\left.3^{\text {rd }}\right), 77.78 \%\left(4^{\text {th }}\right)$ and $58.33 \%\left(5^{\text {th }}\right)$. Areas under the curve were $78.95 \%\left(1^{\text {st }}\right), 84.69 \%$ $\left(2^{\text {nd }}\right), 88.04 \%\left(3^{\text {rd }}\right)$ and $78.95 \%\left(4^{\text {th }}\right.$ and $\left.5^{\text {th }}\right) . \mathrm{FEV}_{1}$ and $\mathrm{PaO}_{2 \text { ground }}$ were correlated with HAST results. Conclusions: The 3 rd equation gave the best predictions in comparison with results obtained by HAST. However, because the individual differences found were substantial for all equations, we still recommend performing a HAST whenever possible to confidently access in-flight hypoxia and the need for oxygen. 
Keywords: Cystic Fibrosis, Altitude, Hypoxia

\section{Introduction}

The quality of life and life expectancy of patients with cystic fibrosis (CF) have increased substantially during the past years ${ }^{1}$ due to medical improvement and preventive initiatives, which currently enable these patients to participate in activities that were not previously feasible, such as tourism. ${ }^{2}$ As a result, physicians are increasingly requested to evaluate these patients for their ability to fly safely and the need for oxygen supplementation. ${ }^{3,4}$ Commercial flights expose individuals to a lower atmospheric pressure and consequently to a lower oxygen content, ${ }^{2}$ as passenger cabins of commercial aircraft at maximal cruising altitude are pressurized to an altitude equivalent of $2438 \mathrm{~m}$ (8000 feet) ${ }^{1,3,5-7}$ which is equivalent to breathing $15 \%$ oxygen at sea level. ${ }^{3-10}$ This altitude hypobaric hypoxia can be tolerated in healthy individuals, but may cause severe hypoxemia in patients with pulmonary disease. ${ }^{3,10-14} \mathrm{CF}$-patients are therefore prone to a substantial and unsafe reduction in the partial arterial oxygen pressure $\left(\mathrm{PaO}_{2}\right)$ during the flight ${ }^{1,12}$ that may lead to a severe respiratory decompensation. ${ }^{15}$

The Aerospace Medical Association ${ }^{2}$ and British Thoracic Society (BTS) ${ }^{4}$ recommend to perform a hypoxic altitude simulation test (HAST) to assess whether patients need in-flight oxygen supplementation. The HAST is considered the gold standard ${ }^{11}$ and it can be done by artificially reducing inspired oxygen to similar levels as those experienced at $2438 \mathrm{~m}$ ( 8000 feet) for $20 \mathrm{~min}$ by either reducing the fraction of inspired oxygen to $15 \% \%^{1,4,7,11}$ or by reducing atmospheric pressure to 565 Torr (75 $\mathrm{kPa}$ ) in a hypobaric chamber. ${ }^{4,11}$ The normobaric HAST is usually the preferred technique, as it is more accessible and inexpensive than the HAST performed in a hypobaric chamber. The expected $\mathrm{PaO}_{2}\left(\mathrm{PaO}_{2 \mathrm{HAST}}\right)$ is then determined from measurements of arterial blood gases $(\mathrm{ABG}) .{ }^{11} \mathrm{~A}$ subject is judged to require in-flight oxygen supplementation if the $\mathrm{PaO}_{2 \mathrm{HAST}}$ falls below $50 \mathrm{mmHg}$, although this arbitrary cut-off value has little supporting evidence. ${ }^{4}$

Security cut-offs have been proposed that can be used when HAST is not available. In the case of $\mathrm{CF}$, patients with $\mathrm{FEV}_{1}>50 \%$ or $\mathrm{PaO}_{2 \text { ground }}>60 \mathrm{mmHg}$ can safely be allowed to travel without oxygen supplementation. ${ }^{3,12}$ In addition, several investigators have developed predictive equations that estimate $\mathrm{PaO}_{2}$ at altitude $\left(\mathrm{PaO}_{2 a l t}\right)$ using measurements made at sea level. . $^{611,14,16,17}$ The BTS guidelines refers to four of them, but they have been derived almost exclusively from patients with chronic obstructive pulmonary disease who undergone a HAST. ${ }^{4}$ Only one study, performed by 
Kamin et al. ${ }^{17}$ (in our study referred as $5^{\text {th }}$ equation ) testing 12 adults with $\mathrm{CF}$ with mild to moderate respiratory insufficiency (mean $\mathrm{PaO}_{2}$ : $79 \mathrm{mmHg}$ ) proposed one equation to predict the expected hypoxemia for flights of up to 3,5 hours in duration. ${ }^{17}$

The aim of this study was to compare HAST results with those predicted by the available equations in a population of adults diagnosed with $\mathrm{CF}$ in order to evaluate their performance in distinguishing those who need in-flight oxygen supplementation from those who do not.

\section{Materials and Methods}

CF-patients, followed in our unit, aged over 18 years old, with stable disease, who intent to fly in the future were recruited. Thirty CF-patients were included in our study. To recruit healthy adults, an open call was launched by e-mail among medical students and young medical doctors. The participants had to fill a questionnaire with known diseases, current chronic medication, symptoms during previous flights and intention to fly in future. Individuals aged under 18 years old, with previous known diseases, symptoms during previous flights or with no intention to fly were excluded. We randomly selected 58 healthy adults. For both groups, we recorded age, sex, weight, height, body mass index (BMI) and smoking habits. Both spirometry and HAST was performed in CFpatients in a period of clinical stability with no change in their usual medication.

Spirometry breathing room air at sea level (Lisbon, $2 \mathrm{~m}$ above sea level, hereafter referred to as sea level) was performed before HAST using body screen from Viasys (Conshohocken, Pennsylvania, US) and the reference equation of Quanjer et al. ${ }^{18}$ to determine forced expiratory volume in 1 second $\left(\mathrm{FEV}_{1}\right)$, Forced vital capacity (FVC) and calculate $\mathrm{FEV}_{1} / \mathrm{FVC}$.

The normobaric HAST was performed at sea level and according to the recommendations of the $\mathrm{BTS}^{4}$ and Vohra and Klocke method ${ }^{19}$. Briefly, following this protocol, participants had to breath a $\mathrm{FiO}_{2}$ of $15 \%$ using a gas mixture with a supply of 99.993\% nitrogen (Linde Healthcare, Lisboa, Portugal) through a 40\% flow Venturi mask (Intersurgical, Berkshire, UK). Cardiorespiratory monitoring was performed using a polygraph and an oximeter in a hand finger (Alice PDX; Philips-Respironics, Murrysville, PA, USA; Nonin Medical, Plymouth, MN, USA). Parameters monitored included oxygen peripheral saturation, arterial pressure (Classic Check, Pic solution, Artsana, Grandate, Italy) and electrocardiography. As established by BTS, recommended HCT duration is between 20 and $25 \mathrm{~min}$. Immediately before and $30 \mathrm{~min}$ after provocation an ABG sample was drawn and immediately analyzed (Rapid point 
500, Siemens, Erlangen, Germany), to measure $\mathrm{PaO}_{2 \text { ground, oxygen saturation at ground }}$ ( $\left.\mathrm{SatO}_{2 \text { ground }}\right), \mathrm{PaO}_{2 \text { HALT }}$ and oxygen saturation after HAST $\left(\mathrm{SatO}_{2 \mathrm{HAST}}\right)$. HAST results were then compared with the predictions made by the following equations:

- $1^{\text {st }}$ equation (Dillard et al.) ${ }^{14}: \mathrm{PaO}_{2 \mathrm{alt}}=0,410 \times \mathrm{PaO}_{2 \text { ground }}+17,652$;

- $2^{\text {nd }}$ equation (Dillard et al.) ${ }^{14}: \mathrm{PaO}_{2 a l t}=0,519 \times \mathrm{PaO}_{2 \text { ground }}+11,855 \times \mathrm{FEV}_{1}(\mathrm{~L})$ 1,760

- $3^{\text {rd }}$ equation (Dillard et al.) $)^{14}: \mathrm{PaO}_{2 \text { alt }}=0,453 \times \mathrm{PaO}_{2 \text { ground }}+0,386 \times \mathrm{FEV}_{1}(\%)+2,44$;

- $4^{\text {th }}$ equation (Gong et al. $)^{16}: \mathrm{PaO}_{2 \text { alt }}=0,88+0,68 \times \mathrm{PaO}_{2 \text { ground; }}$;

- $5^{\text {th }}$ equation (Kamin et al. $)^{17}: \mathrm{PaO}_{2 \text { alt }}=\mathrm{PaO}_{2 \text { ground }}-26,6$.

\section{Statistical analysis}

Clinical characteristic, spirometry and ABG results were analyzed and compared in the healthy controls and CF patients. Normal distribution of the data was assessed using Shapiro-Wilk test; Student's $t$-test was performed for data with a normal distribution, and the non-parametric Wilcoxon test when that was not the case. The Chi-square test was preferred for categorical variables. To verify the effectiveness of the five equations in separating who needs oxygen during the flight from those who do not, receiving operator characteristic (ROC) curves were performed and the area under the curve (AUC) was calculated for each equation. This study was approved by the Research Ethics Committee of Centro Hospitalar Lisboa Norte (Lisboa, Portugal).

\section{Results}

Out of the 88 randomly selected adults, all were caucasians and the majority were women (52.27\%) with a median age of 22 years old. Between CF-patients and the healthy controls, there was a significant difference in weight, height and body mass index (BMI) $(p<0.001)$, with CF-patients being thinner and shorter. In the control group, $18.96 \%$ were former smokers and $12.06 \%$ current smokers, while all of the CF-patients were non-smoker. No statistically significant difference was found for age and gender. Clinical characteristics of the sample studied are summarized in Table 1.

We found significant differences when comparing the recorded functional respiratory values: CF-patients had lower FVC, FEV 1 and FEV $\left.\mathrm{FEVC}_{1} / \mathrm{FV}<0.001\right)$. CFpatients had also lower $\mathrm{PaO}_{2 \text { ground }}$, $\mathrm{SatO}_{2 \text { ground }}, \mathrm{PaO}_{2 \mathrm{HALT}}$, $\mathrm{SatO}_{2 \mathrm{HAST}}$ and lower minimal oxygen saturation $\left(\mathrm{SpO}_{2} \mathrm{~min}\right)$ measured during HAST $(p<0.001)$. Respiratory functional results are summarized in Table 2. 
None of the healthy controls reached a $\mathrm{PaO}_{2 \mathrm{HAST}}$ below $50 \mathrm{mmHg}$, while 11 (36.7\%) of the CF-patients had lower values, with $42.7 \mathrm{mmHg}$ being the lowest founded value - Table 3 .

When CF-patients were divided by $\mathrm{PaO}_{2 \mathrm{HAST}}$ (below or above $50 \mathrm{mmHg}$ ), a significant difference was found for weight $(p=0.002)$, BMI $(p<0.002), \mathrm{FVC}, \mathrm{FEV}_{1}$ $(p<0.001), \mathrm{FEV}_{1} / \mathrm{FVC}(p=0.003), \mathrm{PaO}_{2 \text { ground }}(p=0.008)$ and $\mathrm{SatO}_{2 \text { ground }}(p<0.007)$, with patients with $\mathrm{PaO}_{2 \mathrm{HAST}}<50 \mathrm{mmHg}$ having lower values. No difference was found for age $(p=1)$, gender $(p=0.466)$ or height $(p=0.219)$ between CF-patients.

\section{Adjustment between groups}

As the healthy controls and CF-patients have significant differences, we performed an adjustment for tobacco usage, BMI and height. All smokers and former smokers were excluded. Out of the 70 non-smoker adults (40 healthy controls and $30 \mathrm{CF}$-patients), the majority were women (54.28\%) with a median age of 22 years old. Between CFpatients and the healthy controls, as expected, there was a significant difference in weight $(p<0.001)$, height $(p=0.003)$ and BMI $(p<0.001)$. No statistically significant difference was found for age $(p=0.092)$ and gender $(p=1)$.

Significant differences were found when analyzing functional respiratory values: CF-patients had lower FVC, $\mathrm{FEV}_{1}$ and $\mathrm{FEV}_{1} / \mathrm{FVC}(p<0.001)$. CF-patients had also lower $\mathrm{PaO}_{2 \text { ground, }} \mathrm{SatO}_{2 \text { ground, }} \mathrm{PaO}_{2 \mathrm{HAST}}$, $\mathrm{SatO}_{2 \mathrm{HAST}}(p<0.001)$ and a lower $\mathrm{SpO}_{2}$ min measured during HAST $(p<0.001)$.

With all five equations, the mean predicted $\mathrm{PaO}_{2 a l t}$ had a significant difference between healthy controls and CF-patients $(p<0.001)$. When the five equations were compared to each other, the mean predicted $\mathrm{PaO}_{2 \text { alt }}$ had also a significant difference ( $p \leq 0.005)$, but when a cut-off of $50 \mathrm{mmHg}$ was used, no difference was found $(p=0,51)$.

To prevent a confounding effect by BMI and height, we used a correction based on multiple linear regression. This method allows to take into consideration the variability associated with each factor. A significant difference was still found between the groups on FVC, $\mathrm{FEV}_{1}$ and $\mathrm{FEV}_{1} / \mathrm{FVC}, \mathrm{PaO}_{2 \text { ground, }} \mathrm{SatO}_{2 \text { ground, }} \mathrm{PaO}_{2 \mathrm{HAST}}$, $\mathrm{SatO}_{2 \mathrm{HAST}}$, $\mathrm{SpO}_{2}$ min and predicted $\mathrm{PaO}_{2 \text { alt }}$ by the five equations $(p<0.001)$.

\section{Equation comparison}

Healthy adults and CF-patients: When the values of $\mathrm{PaO}_{2}$ alt in the healthy controls and CF-patients were compared, a significant difference was found in all five equations $(p<0.001)$. The lowest predicted $\mathrm{PaO}_{2 \text { alt }}$ was found with the $5^{\text {th }}$ equation, on the $\mathrm{CF}$ - 
patient group (34.2 $\mathrm{mmHg}$ ) - Table 3 . This value was lower than the respective $\mathrm{PaO}_{2 \mathrm{HAST}}$ found. When a cut-off of $50 \mathrm{mmHg}$ for $\mathrm{PaO}_{2 \text { alt }}$ was used, none of the control had a predicted $\mathrm{PaO}_{2 \text { alt }}<50 \mathrm{mmHg}$. We used a non-parametrical approach for all variables when $\mathrm{CF}$-patients were divided by $\mathrm{PaO}_{2 \mathrm{HAST}}$ (below or above $50 \mathrm{mmHg}$ ), because the groups became smaller. In this case, a significant difference was found for weight $(p=0.002)$, BMI $(p<0.002), \mathrm{FVC}, \mathrm{FEV}_{1}(p<0.001), \mathrm{FEV}_{1} / \mathrm{FVC}(p=0.003)$, $\mathrm{PaO}_{2 \text { ground }}(p=0.008)$ and $\mathrm{SatO}_{2 \text { ground }}(p<0.007)$. Patients with $\mathrm{PaO}_{2 \mathrm{HAST}}<50 \mathrm{mmHg}$ had the lowest values. No difference was found on age $(p=1)$, gender $(p=0.466)$ or height ( $p=0.219)$ between CF-patients.

Using this cut-off, there were no evidences of significant differences between the case distribution among the equations ( $p=0.369)$. However, when we compare with the case distribution based on the results from the HAST test, some CF-patients were misclassified - Table 4 and Table 5.

We found no statistically significant difference on the sensibility of each equation (63.64\%) and the specificity was $63.16 \%$ ( $1^{\text {st }}$ equation), $94.74 \%\left(2^{\text {nd }}\right.$ and $\left.3^{\text {rd }}\right)$, $89.47 \%\left(4^{\text {th }}\right)$ and $74.68 \%\left(5^{\text {th }}\right)$. The positive predictive value was $50 \%\left(1^{\text {st }}\right.$ equation $)$, $87.5 \%\left(2^{\text {nd }}\right.$ and $\left.3^{\text {rd }}\right), 77.78 \%\left(4^{\text {th }}\right)$ and $58.33 \%\left(5^{\text {th }}\right)$. The negative predictive value was $75 \%\left(1^{\text {st }}\right.$ equation $), 81.82 \%\left(2^{\text {nd }}\right.$ and $\left.3^{\text {rd }}\right), 80.95 \%\left(4^{\text {th }}\right)$ and $77.78 \%\left(5^{\text {th }}\right)$.

In order to compare the performance of the five equations with the cut-off of $50 \mathrm{mmHg}$, ROC curves were performed (Figure 1). The $3^{\text {rd }}$ equation had the best performance with an AUC of 88.04\%.

\section{Prediction of in-flight oxygen need in CF-patients}

To test whether the requirement for in-flight oxygen supplementation could be predicted by $\mathrm{PaO}_{2}$ ground and/or by $\mathrm{FEV}_{1}$ (in Liters and predicted percentage), we analyzed the CF-patients with $\mathrm{PaO}_{2 \mathrm{HAST}}<50 \mathrm{mmHg}(\mathrm{n}=11)$. Of this sub-group eight (72.73\%) had $\mathrm{FEV}_{1}<50 \%$, six $(54.55 \%)$ had $\mathrm{PaO}_{2 \text { ground }}<70 \mathrm{mmHg}$, two of which had $<65 \mathrm{mmHg}$.

A relation between $\mathrm{FEV}_{1 \text { (in liters) }} / \mathrm{PaO}_{2 \mathrm{HAST}}, \mathrm{FEV}_{1(\%)} / \mathrm{PaO}_{2 \mathrm{HAST}}$ and $\mathrm{PaO}_{2 \text { ground }} /$ $\mathrm{PaO}_{2 \text { HAST }}$ was found $(p<0.001)-$ Figure 2 .

Out of the patients that required in-flight oxygen supplementation, 10 had $\mathrm{FEV}_{1}$ $<2$ Liters, one $\mathrm{FEV}_{1}>3$ Liters, all had $\mathrm{FEV}_{1}<60 \%$ of the predicted value and $\mathrm{PaO}_{2 \text { ground }}>60 \mathrm{mmHg}$, with one patient having $\mathrm{PaO}_{2 \text { ground }}>90 \mathrm{mmHg}$. 


\section{Discussion}

Guidelines refer to predictive equations of altitude hypoxia as either a screening tool for recommending a HAST or as a replacement when this test is not available, ${ }^{11}$ but the accuracy and predictive value of the available equation in relation to the HAST Gold Standard has not been previously evaluated in CF patients in comparison to healthy individuals. In our sample, we found a significant difference between healthy and CFpatients even when adjusted for tobacco usage, BMI or height. In our sample, $11 \mathrm{CF}$ patients and none of the healthy controls reached a $\mathrm{PaO}_{2 \mathrm{HAST}}$ below $50 \mathrm{mmHg}$. Patients who needed in-flight oxygen supplementation were thinner, had lower FVC, FEV $\mathrm{FEV}_{1} / \mathrm{FVC}, \mathrm{PaO}_{2 \text { ground }}$ and $\mathrm{SatO}_{2 \text { ground }}$ than those who did not.

While the $3^{\text {rd }}$ equation performed better than the other four, when compared to HAST results, none was able to correctly identify CF-patients that required in-flight oxygen supplementation. In a previous study, Martin et al. ${ }^{5}$ tested the prediction of the first four equations in 15 adults with $\mathrm{CF}$ and concluded that the four equations overestimated the need of in-flight oxygen. In our sample, only the first and fifth equations overestimated the HAST results. While overestimation will lead to unnecessary prescription of oxygen in flight with no clinical risk but increasing flight cost, possibly making the trip unfeasible, the opposite could lead a significant clinical risk. Therefore, we do not recommend to use these equations as screening tools or substitute of HAST.

According to some literature, ${ }_{, 2} \mathrm{CF}$-patients with $\mathrm{FEV}_{1}>50 \%$ or $\mathrm{PaO}_{2 \text { ground }}>60$ mmHg can safely travel without oxygen supplementation. Therefore, this recommendation would exempt the performance of HAST in these patients. In fact, in our sample, $\mathrm{FEV}_{1}$ and $\mathrm{PaO}_{2}$ ground correlated with $\mathrm{HAST}$ results, with $\mathrm{FEV}_{1}$ in predicted percentage being the most accurate. However, contrary to the recommendations described above, all patients that needed in-flight oxygen had a $\mathrm{FEV}_{1}<60 \%$ while no other cut-off on $\mathrm{FEV}_{1}$ in Liters or $\mathrm{PaO}_{2 \text { ground }}$ was able to correctly predict those who reached $\mathrm{PaO}_{2 \mathrm{HAST}}$ below $50 \mathrm{mmHg}$. We do not recommend to use the previous values of $\mathrm{FEV}_{1}\left(>50 \%\right.$ of the predicted value) or $\mathrm{PaO}_{2 \text { ground }}(>60 \mathrm{mmHg})$ as, in our sample, tree patients with $\mathrm{FEV}_{1}>50 \%$ and all 11 patients that needed in-flight oxygen had $\mathrm{PaO}_{2 \text { ground }}>60 \mathrm{mmHg}$.

We found a large variability between the results given by HAST and the values predicted by the different equations studied. The third equation produced predictions closer to the results observed by HAST, but given the individual difference found, the 
bioRxiv preprint doi: https://doi.org/10.1101/570754; this version posted March 9, 2019. The copyright holder for this preprint (which was

not certified by peer review) is the author/funder. All rights reserved. No reuse allowed without permission.

authors recommend to, whenever possible, perform a HAST to analyze commercial air flights risks. 
Table 1 - Clinical characteristics of the sample studied.

\begin{tabular}{|c|c|c|c|c|}
\hline Characteristics & $\begin{array}{l}\text { Total } \\
(\mathrm{n}=\mathbf{8 8})\end{array}$ & $\begin{array}{l}\text { CF patients } \\
(\mathrm{n}=30)\end{array}$ & $\begin{array}{l}\text { Healthy controls } \\
(\mathrm{n}=58)\end{array}$ & $p$-value \\
\hline Age, years ${ }^{\dagger}$ & $22[21 ; 24]$ & $23[21.25 ; 30.75]$ & $22[21 ; 23]$ & 0.099 \\
\hline Gender - Men, n (\%) & $42(47.72)$ & $14(46.66)$ & $28(48.27)$ & 1 \\
\hline Weight, kg $^{\dagger}$ & $61[53.75 ; 70.5]$ & $53[50 ; 61.5]$ & $65[57.25 ; 75]$ & $<0.001$ \\
\hline Height, cm $^{*}$ & $167.52 \pm 8.94$ & $163.3 \pm 7.02$ & $169.71 \pm 9.08$ & $<0.001$ \\
\hline BMI, $\mathbf{k g} / \mathbf{m}^{2 \dagger}$ & $22.23[19.84 ; 23.87]$ & $19.93[18.99 ; 21.92]$ & $23.08[21.81 ; 23.25]$ & $<0.001$ \\
\hline Non-smokers, n (\%) & $70(79.54)$ & $30(100)$ & $40(69.96)$ & $<0.001$ \\
\hline
\end{tabular}

${ }^{*}$ : mean \pm standard deviation; ${ }^{\dagger}$ : median [interquartile range]; BMI: Body mass index.

Table 2 - Respiratory functional results of the sample studied.

\begin{tabular}{|c|c|c|c|c|}
\hline Results & $\begin{array}{l}\text { Total } \\
(n=88)\end{array}$ & $\begin{array}{l}\text { CF patients } \\
(n=30)\end{array}$ & $\begin{array}{l}\text { Healthy controls } \\
(n=58)\end{array}$ & $p$-value \\
\hline $\mathbf{F V C}, \mathbf{L}^{\dagger}$ & $3.74[3.09 ; 4.75]$ & $2.76[2.35 ; 3.23]$ & $4.21[3.62 ; 5.23]$ & $<0.001$ \\
\hline FVC, $\%^{\dagger}$ & $95.50[81.5 ; 104]$ & $72.5[60.5 ; 82]$ & $101[94.25 ; 108]$ & $<0.001$ \\
\hline $\mathrm{FEV}_{1}, \mathbf{L}^{\dagger}$ & $3.32[2.23 ; 4.04]$ & $1.7[1.18 ; 2.5]$ & $3.66[3.28 ; 4.42]$ & $<0.001$ \\
\hline $\operatorname{FEV}_{1}, \%$ & $93[71.75 ; 104]$ & $56[37.25 ; 71.75]$ & $103[93 ; 208.75]$ & $<0.001$ \\
\hline $\mathrm{FEV}_{1} / \mathrm{FVC}, \%^{\text {}^{* *}}$ & $84.9[72.77 ; 88.26]$ & $63.3[53 ; 73.13]$ & $86.58[82.58 ; 91]$ & $<0.001$ \\
\hline $\mathrm{PaO}_{\text {2ground, }}, \mathrm{mmHg}^{\dagger}$ & $95.7[85.9 ; 99.88]$ & $80.25[71.68 ; 90.75]$ & $98.2[94.98 ; 109.1]$ & $<0.001$ \\
\hline $\mathbf{P a O}_{2 \text { HAST }}, \mathbf{m m H g}^{\dagger}$ & $66.7[59.13 ; 70.9]$ & $53.45[45.9 ; 59.38]$ & $69.35[65.48 ; 73.35]$ & $<0.001$ \\
\hline SatO$_{\text {2ground }}, \%^{\dagger}$ & $97.5[96.7 ; 97.73]$ & 96.05 [94.35; 97] & $97.65[97.4 ; 97.9]$ & $<0.001$ \\
\hline SatO $_{2 \text { HAST }}, \%^{\dagger}$ & $93.5[91.35 ; 97.8]$ & $89.15[83.85 ; 91.7]$ & $94.4[93.13 ; 95.15]$ & $<0.001$ \\
\hline $\mathrm{SpO}_{2} \mathrm{~min}, \%^{\dagger}$ & $88[85 ; 93]$ & $83[80 ; 85.75]$ & $88.5[87.25 ; 90.75]$ & $<0.001$ \\
\hline
\end{tabular}

${ }^{\dagger}$ : median [interquartile range]; * using the reference equation of Quanjer et al. ${ }^{18}$; FVC: Forced volume capacity; L: Liters; $\mathrm{FEV}_{1}$ : Forced expiratory volume in 1 second; $\mathrm{PaO}_{2 \text { groud: }}$ partial arterial oxygen pressure measured at ground; $\mathrm{PaO}_{2 \text { наSт: }}$ partial arterial oxygen pressure measured at the end of the hypoxia challenge test; $\mathrm{SatO}_{2 \text { ground: }}$ oxygen saturation at ground measured by arterial blood gas; $\mathrm{SatO}_{2 \mathrm{HAST}}$ : oxygen saturation at the end of the hypoxia challenge test measured by arterial blood gas; $\mathrm{SpO}_{2}$ min: lower minimal oxygen saturation measured during the hypoxia challenge test measured by finger probe. 
Table 3 - Mean $\mathrm{PaO}_{2}$ at altitude $(\mathrm{mmHg})$ by HAST and predicted the five equations.

\begin{tabular}{|c|c|c|c|c|}
\hline & $\begin{array}{l}\text { Total } \\
(\mathrm{n}=\mathbf{8 8})\end{array}$ & $\begin{array}{l}\text { CF patients } \\
(n=30)\end{array}$ & $\begin{array}{l}\text { Healthy controls } \\
(\mathrm{n}=58)\end{array}$ & $p$-value \\
\hline $\begin{array}{l}\text { HAST } \\
\text { Lowest value }\end{array}$ & $\begin{array}{l}64.78 \pm 11.18 \\
42.70\end{array}$ & $\begin{array}{l}54.31 \pm 9.32 \\
42.70\end{array}$ & $\begin{array}{l}70.59 \pm 7.21 \\
59.20\end{array}$ & $<0.001$ \\
\hline $\begin{array}{l}\mathbf{1}^{\text {st }} \text { equation* } \\
\text { Lowest value }\end{array}$ & $\begin{array}{l}55.45 \pm 4.74 \\
42.58\end{array}$ & $\begin{array}{l}50.81 \pm 4.69 \\
42.58\end{array}$ & $\begin{array}{l}57.85 \pm 2.44 \\
51.11\end{array}$ & $<0.001$ \\
\hline $\begin{array}{l}\mathbf{2}^{\text {nd }} \text { equation } \\
\text { Lowest value }\end{array}$ & $\begin{array}{l}83.74 \pm 19.21 \\
37.58\end{array}$ & $\begin{array}{l}63.06 \pm 16.34 \\
37.58\end{array}$ & $\begin{array}{l}94.44 \pm 9.28 \\
76.54\end{array}$ & $<0.001$ \\
\hline $\begin{array}{l}\mathbf{3}^{\text {rd }} \text { equation } \\
\text { Lowest value }\end{array}$ & $\begin{array}{l}77.46 \pm 15.22 \\
38.75\end{array}$ & $\begin{array}{l}60.38 \pm 13.54 \\
38.75\end{array}$ & $\begin{array}{l}86.29 \pm 5.24 \\
74.14\end{array}$ & $<0.001$ \\
\hline $\begin{array}{l}4^{\text {th }} \text { equation* } \\
\text { Lowest value }\end{array}$ & $\begin{array}{l}63.57 \pm 7.87 \\
42.22\end{array}$ & $\begin{array}{l}55.87 \pm 7.77 \\
42.22\end{array}$ & $\begin{array}{l}67.55 \pm 4.05 \\
56.37\end{array}$ & $<0.001$ \\
\hline $\begin{array}{l}5^{\text {th }} \text { equation* } \\
\text { Lowest value }\end{array}$ & $\begin{array}{l}65.59 \pm 11.57 \\
34.20\end{array}$ & $\begin{array}{l}54.27 \pm 11.43 \\
34.20\end{array}$ & $\begin{array}{l}71.44 \pm 5.96 \\
55\end{array}$ & $<0.001$ \\
\hline
\end{tabular}

Table 4 - Division of CF-patients by predicted $\mathrm{PaO}_{2}$ at altitude $\left(\mathrm{PaO}_{2}\right.$ alt, $\left.\mathrm{mmHg}\right)$ by the five equations.

\begin{tabular}{|l|l|l|l|}
\hline \multirow{2}{*}{ Equation } & \multicolumn{2}{|c|}{ Predicted $\mathbf{P a O}_{2 \text { alt }}$} & \multirow{2}{*}{-value } \\
\cline { 2 - 3 } & $<\mathbf{5 0} \mathbf{~ m m H g}$ & $>\mathbf{5 0} \mathbf{m m H g}$ & \\
\hline $\mathbf{1}^{\text {st }}$ equation & 14 & 16 & \multirow{2}{*}{0.369} \\
\hline $\mathbf{2}^{\text {nd }}$ equation & 8 & 22 & \\
\hline $3^{\text {rd }}$ equation & 8 & 22 & \\
\hline $\mathbf{4}^{\text {th }}$ equation & 9 & 21 & \\
\hline $\mathbf{5}^{\text {th }}$ equation & 12 & 18 & \\
\hline
\end{tabular}

Table 5 - Division of CF-patients by HAST results and by predicted $\mathrm{PaO}_{2}$ at altitude $\left(\mathrm{PaO}_{2 \text { alt }}, \mathrm{mmHg}\right)$ by the five equations.

\begin{tabular}{|c|c|c|c|c|c|c|c|c|c|c|c|}
\hline & \multicolumn{2}{|c|}{$1^{\text {st }}$ equation } & \multicolumn{2}{|c|}{$2^{\text {nd }}$ equation } & \multicolumn{2}{|c|}{$3^{\text {rd }}$ equation } & \multicolumn{2}{|c|}{$4^{\text {th }}$ equation } & \multicolumn{2}{|c|}{$5^{\text {th }}$ equation } \\
\hline & & $\begin{array}{c}<50 \\
\mathrm{mmHg}\end{array}$ & $\begin{array}{c}>50 \\
\mathrm{mmHg}\end{array}$ & $\begin{array}{c}<50 \\
\mathrm{mmHg}\end{array}$ & $\begin{array}{c}>50 \\
\mathrm{mmHg}\end{array}$ & $\begin{array}{c}<50 \\
\mathrm{mmHg}\end{array}$ & $\begin{array}{c}>50 \\
\mathrm{mmHg}\end{array}$ & $\begin{array}{c}<50 \\
\mathrm{mmHg}\end{array}$ & $\begin{array}{c}>50 \\
\mathrm{mmHg}\end{array}$ & $\begin{array}{c}<50 \\
\mathrm{mmHg}\end{array}$ & $\begin{array}{c}>50 \\
\mathrm{mmHg}\end{array}$ \\
\hline \multirow{2}{*}{$\begin{array}{l}\text { HAST } \\
\text { results }\end{array}$} & $\begin{array}{c}<50 \\
\mathrm{mmHg}\end{array}$ & 7 & 4 & 7 & 4 & 7 & 4 & 7 & 4 & 7 & 4 \\
\hline & $\begin{array}{c}>50 \\
\mathrm{mmHg}\end{array}$ & 7 & 12 & 1 & 18 & 1 & 18 & 2 & 17 & 5 & 14 \\
\hline
\end{tabular}


$1^{\text {st }}$ equation

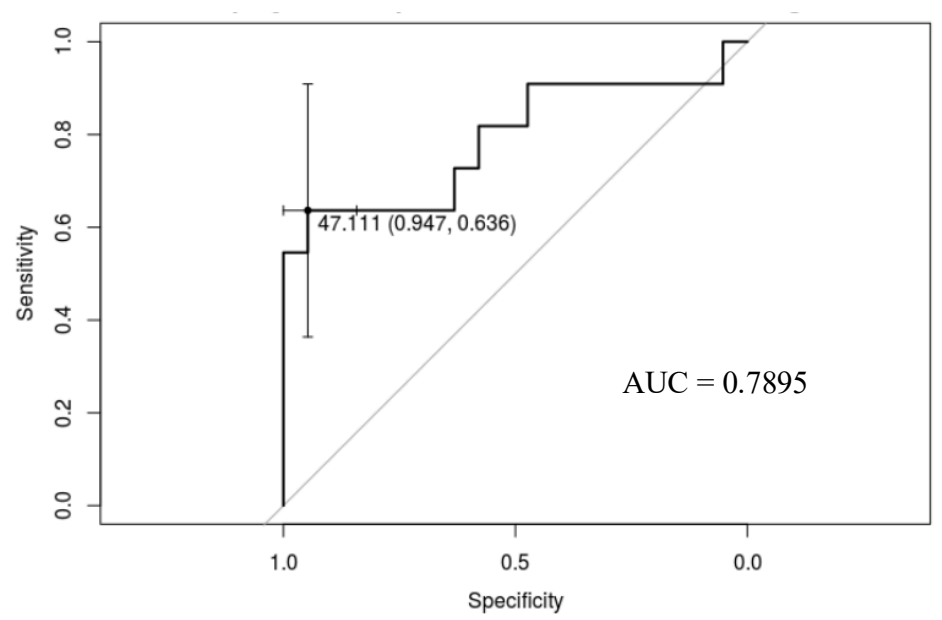

$3^{\text {rd }}$ equation

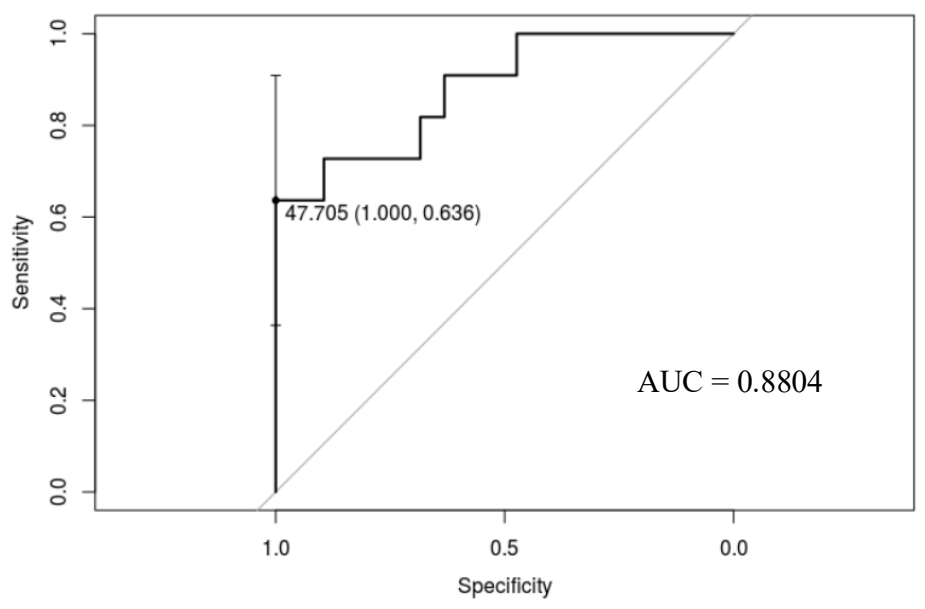

$2^{\text {nd }}$ equation

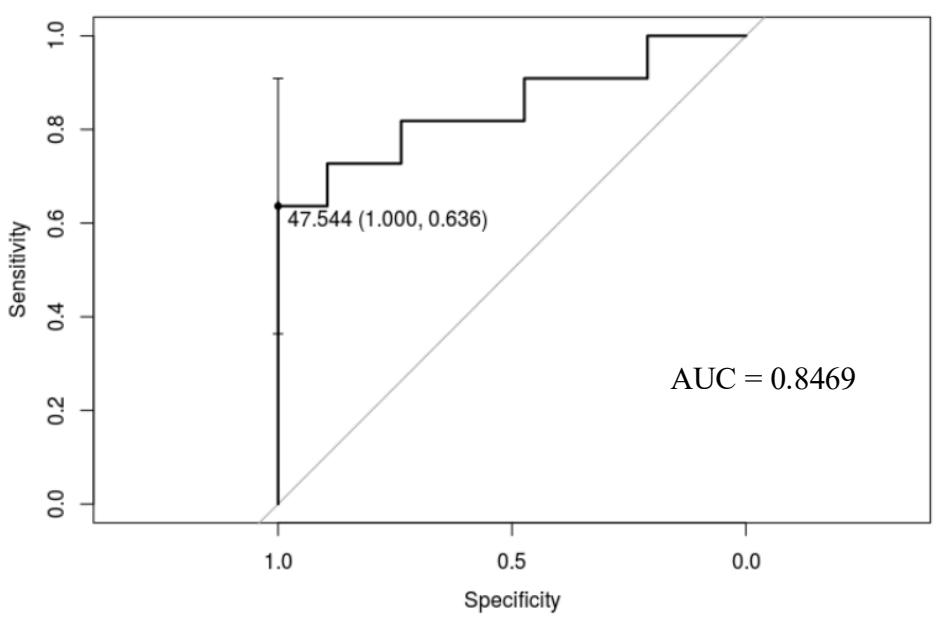

$4^{\text {th }}$ equation



$5^{\text {th }}$ equation



Figure 1- Receiving Operator Characteristic (ROC) curves and Area Under the Curve (AUC) of the five equations analyzed. 
A)



B)








Figure 2- Relation between: (A) $\mathrm{FEV}_{1 \text { (in liters) }} / \mathrm{PaO}_{2 \mathrm{HAST}}$; (B) $\mathrm{FEV}_{1(\%)} / \mathrm{PaO}_{2 \mathrm{HAST}}$; (C) $\mathrm{PaO}_{2 \text { ground }} / \mathrm{PaO}_{2 \text { HAST }}$.

\section{Acknowledgements}

The authors are grateful to the staff of Serviço de Pneumologia, Departamento do Tórax, 1649-035 Lisboa, Portugal for technical support. No specific grant from funding agencies in the public, commercial, or not-for-profit sectors was used to support this research.

Declarations of interest: none. 


\section{References}

1. Edvardsen E, Akero A, Skjonsberg OH, Skrede B. Pre-flight evaluation of adult patients with cystic fibrosis: a cross-sectional study. BMC research notes. 2017; 10(1):84.

2. Hirche TO, Department of Pulmonary Medicine GCfDWG, Bradley J, et al. Travelling with cystic fibrosis: Recommendations for patients and care team members. Journal of Cystic Fibrosis. 2010;9(6):385-399.

3. Fischer R, Lang SM, Bruckner K, et al. Lung function in adults with cystic fibrosis at altitude: impact on air travel. The European respiratory journal. 2005;25(4):718-724.

4. Ahmedzai S, Balfour-Lynn IM, Bewick T, et al. Managing passengers with stable respiratory disease planning air travel: British Thoracic Society recommendations. Thorax. 2011;66(Suppl 1):i1.

5. Martin SE, Bradley JM, Buick JB, Bradbury I, Elborn JS. Flight assessment in patients with respiratory disease: hypoxic challenge testing vs. predictive equations. QJM : monthly journal of the Association of Physicians. 2007;100(6):361-367.

6. Seccombe LM, Kelly PT, Wong CK, Rogers PG, Lim S, Peters MJ. Effect of simulated commercial flight on oxygenation in patients with interstitial lung disease and chronic obstructive pulmonary disease. Thorax. 2004;59(11):966970.

7. Spoorenberg ME, van den Oord MH, Meeuwsen T, Takken T. Fitness to Fly Testing in Patients with Congenital Heart and Lung Disease. Aerospace medicine and human performance. 2016;87(1):54-60.

8. Buchdahl RM, Babiker A, Bush A, Cramer D. Predicting hypoxaemia during flights in children with cystic fibrosis. Thorax. 2001;56(11):877-879.

9. Oades PJ, Buchdahl RM, Bush A. Prediction of hypoxaemia at high altitude in children with cystic fibrosis. BMJ (Clinical research ed). 1994;308(6920):1518.

10. Peckham D, Watson A, Pollard K, Etherington C, Conway SP. Predictors of desaturation during formal hypoxic challenge in adult patients with cystic fibrosis. Journal of cystic fibrosis : official journal of the European Cystic Fibrosis Society. 2004;1(4):281-286.

11. Bradi AC, Faughnan ME, Stanbrook MB, Deschenes-Leek E, Chapman KR. Predicting the need for supplemental oxygen during airline flight in patients with chronic pulmonary disease: A comparison of predictive equations and altitude simulation. Can Respir J. 2009;16(4):119-124.

12. Thews O, Fleck B, Kamin WE, Rose DM. Respiratory function and blood gas variables in cystic fibrosis patients during reduced environmental pressure. European journal of applied physiology. 2004;92(4-5):493-497.

13. Medical Guidelines for Airline Travel, 2nd ed. Aviation, space, and environmental medicine. 2003;74(5 Suppl):A1-19.

14. Dillard TA, Berg BW, Rajagopal KR, Dooley JW, Mehm WJ. Hypoxemia during air travel in patients with chronic obstructive pulmonary disease. Annals of internal medicine. 1989;111(5):362-367.

15. Speechly-Dick ME, Rimmer SJ, Hodson ME. Exacerbations of cystic fibrosis after holidays at high altitude--a cautionary tale. Respiratory medicine. 1992;86(1):55-56.

16. Gong H, Jr., Tashkin DP, Lee EY, Simmons MS. Hypoxia-altitude simulation test. Evaluation of patients with chronic airway obstruction. The American review of respiratory disease. 1984;130(6):980-986. 
17. Kamin W, Fleck B, Rose DM, Thews O, Thielen W. Predicting hypoxia in cystic fibrosis patients during exposure to high altitudes. Journal of cystic fibrosis : official journal of the European Cystic Fibrosis Society. 2006;5(4):223-228.

18. Quanjer PH, Tammeling GJ, Cotes JE, Pedersen OF, Peslin R, Yernault JC. Lung volumes and forced ventilatory flows. Report Working Party Standardization of Lung Function Tests, European Community for Steel and Coal. Official Statement of the European Respiratory Society. The European respiratory journal Supplement. 1993;16:5-40.

19. Vohra KP, Klocke RA. Detection and correction of hypoxemia associated with air travel. The American review of respiratory disease. 1993;148(5):1215-1219. 